\section{Quantification Values}

Akihiro Kojima et al, Journal of Nuclear Medicine, 30(4), 508 514, (1989).

SPECT による定量に対する空間分解能の影響を回転 方式ガンマカメラおよび ${ }^{99 \mathrm{~m}} \mathrm{Tc}$ を用いて検討した。 ホッ トおよびコールド領域を有するファントムを用いて，線 源放射能と SPECT イメージの関係を確認するため，ま た理論計算値と比較するため実験を行った。その結果, ホット領域では対象物の大きさが半值幅 (FWHM) の 2.5倍以上でSPECT 值は真の放射能を示した.コールド 領域では同様の大きさであっても，真の值に対する誤差 は20\%以内であった.さらに，ホット領域の大きさが FWHM の 1.4 倍以上の場合, 最大值の $1 / 2$ のカッオフイ メージの大きさが真の大きさと一致した。また絶対放射 能と全 SPECT 值の関係は, カットオフが 0 であるとき 比例した. 空間分解能の影響を知ることは, 臨床 SPECT 検査にとって必要なことである。

\section{シスプラチン投与患者における骨シンチグラフィ時の取 \\ 異常集積像の検討}

猪狩秀則, 他, 日本医学放射線学会雑誌, 49(8), $1017 \sim 1024 ， 1989$.

最近, 悪性腫瘍に対する化学療法剤としてシスプラチ ン (cis-diamminedichloro platinum, CDDP) が頭頝部 癌, 非小細胞肺癌, 泌尿器系腫瘍, 婦人科領域の腫瘍を 中心に使用されることが多くなってきた.これらの

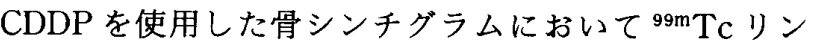
酸化合物が腎実質へびまん性に集積される症例がしばし ば観察され, 特に腰椎より強い集積を呈する「hot kidneys」と呼ばれる像が多く観察されるようになった。

CDDP 投与による腎への異常集積は一過性の現象と 考えられる。異常集積は腎機能低下とほほ平行しており， この現象は CDDP の腎毒性によるものと考えられた。い わゆ「hot kidneys」を呈する原因としては, CDDPの 影響が最も大きな出現因子と思われる。

Considerations for Cardiac Imaging with Indium111-labeled Radiopharmaceuticals

Michael A. King et al., Journal of Nuclear Medicine Technolygy, 17(2), 53 57, (1989).

最近, In-111 標識心筋イメージング製剤(Indium-111 antimyosin Fab）が臨床に用いられる様になった。In111 の利用は，従来より心筋イメージング製剤に用いら れている T1-201, Tc-99m と比較し, 高エネルギーガン マ線を放出するため, 良質な画像が得られることが期待 できる。しかし, 得られる画像は, 使用コリメータ, カ
メラのサイドシールド，クリスタルの厚さなどに左右さ れることが考えられる。今回, LEAP, LEHR, MEMS1 およびMEMS2の 4 種の低エネルギーと中エネルギー 用コリメータを使用し, 回転型ガンマカメラによる画質 の比較検討を行い, 次の結論を得た。

1. 隔壁通過の影響を抑えるためには中エネルギー用 コリメータを使用すべきである.

2. 中エネルギー用コリメータを使用する時は $2 つ の$ photo peak (172keV，247keV) を使うべきである.

3.もし，低エネルギー用コリメータを使用するなら ば, $172 \mathrm{KeV}$ の photo peak で行うべきである.

4. 不十分なサイドシールドのカメラならば $247 \mathrm{KeV}$ を使用する時, 画質が劣化する。

5.メッツフィルタなどのディジタルフィルタで処理 することにより，画質を改善させることができる。

DIGITAL CHEST RADIOGRAPHY WITH A LARGE IMAGE INTENSIFIER Evaluation of diagnostic performance and patient exposure

L.G. M $\AA$ NSON et al., Acta Radiologica, 30(4), $337 \sim 342$, (1989).

大型イメージインテンシファイア (I.I) を備えた胸部 $\mathrm{X}$ 線撮影のデジタルシステムを従来のフィルム・スクリ ーン系のシステムと比較し, その結果について報告して いる.

装置としては，57，47，34 cm の視野を持つ大型 I.I で あり, 像は TVカメラと $100 \mathrm{~mm}$ のスポットカメラに送 られる.モニターは $44 \mathrm{~cm}$ で $1024 \times 1024$ ピクセル, 8 ビッ 卜階調のものである.

評価方法としては, フリーレスポンス ROC と空間解 像度が用いられており，また照射線量についても求めら れている.

結果としては, 空間解像度と同様に低コントラストの 検出率は, 従来のフィルム・スクリーン系の写真の方が デジタルモニタ像と $100 \mathrm{~mm}$ のスポット写真よりも優れ ていると述べている.しかし，透視を患者のポジショニ ングで使用しなければ, I.I システムは従来写真よりも被 暘線量低減になると報告している。

Megavoltage radiation field matching on uneven surface

Jani S.K., et al., Int. J. Radiation Oncology Biol. Phys., 15(5), 1247 1250, (1988).

二つの大照射野の整合部間隔を調節することにより， 整合部の線量が過大および過小とならないようにするこ とは，照射をする現場にとって大切なことである。これ 